\title{
Properties of ( $\mu$-Oxo)di-iron Complexes and Catalytic Activity Toward Cyclohexane Oxidation
}

\author{
Gabrieli L. Parrilha, ${ }^{a}$ Sarah S. Ferreira, ${ }^{a}$ Christiane Fernandes, ${ }^{a}$ Giselle C. Silva, ${ }^{b}$ \\ Nakédia M. F. Carvalho, ${ }^{b}$ O. A. C. Antunes, ${ }^{b, \dagger}$ Valderes Drago, ${ }^{c}$ Adailton J. Bortoluzzi ${ }^{d}$ \\ and Adolfo Horn Jr. *,a
}

${ }^{a}$ Laboratório de Ciências Químicas, Universidade Estadual do Norte Fluminense, 28013-602 Campos dos Goytacazes- RJ, Brazil

${ }^{b}$ Instituto de Química, Universidade Federal do Rio de Janeiro, Cidade Universitária, CT Bloco A-641, 21945-970 Rio de Janeiro-RJ, Brazil

${ }^{c}$ Departamento de Física and ${ }^{d}$ Laboratório de Bioinorgânica e Cristalografia, Departamento de Química, Universidade Federal de Santa Catarina, 88040-900 Florianópolis-SC, Brazil

Neste artigo são apresentadas a síntese e a caracterização de dois compostos binucleares de ferro, os quais contêm uma ponte $\mu$-oxo. Os compostos $\left[\left(\mathrm{SO}_{4}\right)(\mathrm{L} 5) \mathrm{Fe}(\mu-\mathrm{O}) \mathrm{Fe}(\mathrm{L} 5)\left(\mathrm{SO}_{4}\right)\right] \cdot 6 \mathrm{H}_{2} \mathrm{O}, \mathbf{1}$, e $[\mathrm{Cl}(\mathrm{L} 5) \mathrm{Fe}(\mu-\mathrm{O}) \mathrm{Fe}(\mathrm{L} 5) \mathrm{Cl}] \mathrm{Cl}_{2} \cdot 2 \mathrm{H}_{2} \mathrm{O}, 2$, foram obtidos nas reações entre 1-(bis-piridin-2-ilmetilamino)-3-cloropropan-2-ol (L5) e os sais $\mathrm{FeSO}_{4} \cdot 7 \mathrm{H}_{2} \mathrm{O}$ e $\mathrm{FeCl}_{3} \cdot 6 \mathrm{H}_{2} \mathrm{O}$, respectivamente. Os espectros eletrônicos dos complexos apresentam absorções somente na região do ultravioleta, sendo que a análise eletroquímica revelou que, após a formação da espécie $\mathrm{Fe}^{\mathrm{III}} \mathrm{Fe}^{\mathrm{II}}$, a unidade binuclear do composto 1 é mais estável do que a do composto 2 . Os ligantes monodentados (sulfato e cloreto) exercem influência sobre os parâmetros Mössbauer determinados para 1 e 2, particularmente sobre os desdobramentos de quadrupolo. Os compostos foram empregados como catalisadores em reações de oxidação do cicloexano, usando $\mathrm{H}_{2} \mathrm{O}_{2}$ e $t$-BuOOH como oxidantes em uma razão substrato:oxidante:catalisador de 1000:1000:1. Os resultados indicam que o composto 2 é um catalisador mais eficiente que o composto $\mathbf{1}$.

We report herein the synthesis and characterization of two dinuclear $\mu$-oxo iron compounds obtained through the reactions of $\mathrm{FeSO}_{4} \cdot 7 \mathrm{H}_{2} \mathrm{O}$ and $\mathrm{FeCl}_{3} \cdot 6 \mathrm{H}_{2} \mathrm{O}$ with 1-(bis-pyridin-2-ylmethylamino)-3-chloropropan-2-ol (L5), which resulted in the compounds $\left[\left(\mathrm{SO}_{4}\right)(\mathrm{L} 5) \mathrm{Fe}(\mu-\mathrm{O}) \mathrm{Fe}(\mathrm{L} 5)\right.$ $\left.\left(\mathrm{SO}_{4}\right)\right] \cdot 6 \mathrm{H}_{2} \mathrm{O}, \mathbf{1}$, and $[\mathrm{Cl}(\mathrm{L} 5) \mathrm{Fe}(\mu-\mathrm{O}) \mathrm{Fe}(\mathrm{L} 5) \mathrm{Cl}] \mathrm{Cl}_{2} \cdot 2 \mathrm{H}_{2} \mathrm{O}, 2$. The electronic spectra of both compounds show absorption bands only in the UV range. The electrochemical analysis showed that the dinuclear unit is more stable under reduction in compound $\mathbf{1}$ than in compound $\mathbf{2}$, while the Mössbauer spectroscopy revealed that the monodentate ligands (sulfate and chloride) have a significant influence on the Mössbauer parameters determined for $\mathbf{1}$ and 2, particularly on the quadrupole splitting values. Both compounds were studied as catalysts in reactions of cyclohexane oxidation, using $\mathrm{H}_{2} \mathrm{O}_{2}$ and $t$ - $\mathrm{BuOOH}$ as oxidants, in a substrate:oxidant:catalyst ratio of 1000:1000:1. Cyclohexanol, cyclohexanone, cyclohexyl hydroperoxide, $t$-butyl cyclohexyl peroxide and adipic acid were formed during the process. The experiments revealed that compound $\mathbf{2}$ is, in general, more active than compound $\mathbf{1}$ in promoting cyclohexane oxidation.

Keywords: di-iron complex, $\mu$-oxo bridge, methane monooxygenase, cyclohexane oxidation

\section{Introduction}

Under mild conditions, alkanes are inert compounds in the presence of most chemical reagents due to the

${ }^{\dagger}$ Deceased. This paper is dedicated to his memory.

*e-mail: adolfo@uenf.br thermodynamic and kinetic stability of their C-C and $\mathrm{C}-\mathrm{H}$ bonds, which makes their transformation difficult to perform. ${ }^{1}$ The evolution of living systems has provided many ways to overcome this difficulty, such as developing different metalloenzymes, like the cytochrome P-450 family and the methane monooxygenases. These are very 
specialized systems able to promote specific hydrocarbon oxidation. ${ }^{2,3}$

Along with copper, iron was selected by nature to form the majority of natural metalloenzymes, which participate in the oxidation of different organic compounds and have inspired several research groups in the search for the so-called biomimetic compounds that have some functional or structural analogies with the natural systems. ${ }^{4}$ In this regard, several heme and non-heme iron complexes have been employed in studies on hydrocarbon oxidation including those of our group. ${ }^{3-9}$

Soluble methane monooxygenase (sMMO), which is found in methanotrophic bacteria, is one of the natural systems that promote hydrocarbon oxidation, carrying out the conversion of methane to methanol. The active site of this MMO system contains a di-iron center coordinated to the amino acid residues glutamate and histidine, and to water molecules. ${ }^{9}$ During the sMMO catalytic cycle the oxidation state of the iron ions changes from $\mathrm{Fe}^{\mathrm{II}}-\mathrm{Fe}^{\mathrm{II}}$, the most reduced state, to $\mathrm{Fe}^{\mathrm{IV}}-\mathrm{Fe}^{\mathrm{IV}}$, the most oxidized one. The latter is the main reactive species of the cycle, being responsible for the formation and hydroxylation of alkyl radicals. Intermediate species such as $\mathrm{Fe}^{\mathrm{II}}-\mathrm{Fe}^{\mathrm{III}}$ and $\mathrm{Fe}^{\mathrm{III}}-\mathrm{Fe}^{\mathrm{II}}$ have also been characterized in this catalytic cycle. ${ }^{10}$

Several synthetic compounds have been described in the literature as structural and/or functional models for the active site of MMO. For example, the deprotonation of the compound $\left[\mathrm{Fe}_{2}(\mathrm{O})(\mathrm{OH})(6 \mathrm{tla})_{2}\right]\left(\mathrm{ClO}_{4}\right)_{3}(6 \mathrm{tla}=$ tris(6-methylpyridyl-2methyl)amine) resulted in the first diamond core bis( $\mu$-oxo)di-iron(III) compound that mimics the sMMO active site containing $\mathrm{Fe}^{\mathrm{III}} \mathrm{Fe}^{\mathrm{III}}$. ${ }^{11}$ The reaction of $\left[\mathrm{Fe}_{2} \mathrm{O}(5-\mathrm{Me}-\mathrm{tpa})_{2}(\mathrm{OH})\left(\mathrm{H}_{2} \mathrm{O}\right)\right]\left(\mathrm{ClO}_{4}\right)_{3}$ (5-Me-tpa $=$ tris (5-methyl-2-pyridylmethyl)amine) with $\mathrm{H}_{2} \mathrm{O}_{2}$ resulted in a high valence complex containing the $\mathrm{Fe}^{\mathrm{III}}(\mathrm{O})_{2} \mathrm{Fe}^{\mathrm{IV}}$ unit, which has also been characterized by spectroscopic and structural methods and is claimed to be analogous to the intermediate $\mathrm{Q}$ observed in the catalytic cycle of MMO. ${ }^{12}$ Other di-iron complexes have been synthesized as models for the sMMO peroxo intermediate. ${ }^{13}$ From the catalytic point of view, a number of mono and dinuclear iron complexes have been studied in reactions of hydrocarbon oxidation. ${ }^{7,8,14-16}$ In general, cyclohexane is the first substrate chosen as a model, because its manipulation and transformation is much easier than that of methane. Furthermore, the products obtained from cyclohexane oxidation, cyclohexanol and cyclohexanone, are precursors to adipic acid and caprolactam, which have extensive industrial applications in Nylon-6 and Nylon-66 manufacturing. Due to the high amount of energy expended in the actual process, the development of catalytic systems that operate under mild conditions is desired. ${ }^{17}$
In order to contribute to a better understanding of how different ligand groups affect the physicochemical and structural properties of coordination compounds, we have recently published the synthesis and characterization of a family of mononuclear iron complexes containing bis(2pyridylmethyl)amine derivative ligands (Figure 1: L1- L4). Results showing the reactivity of these iron compounds with $\mathrm{H}_{2} \mathrm{O}_{2}$ and $\mathrm{O}_{2}$, as well as their use as catalysts in cyclohexane oxidation, were reported ${ }^{8,18-20}$ Following this same line, we report herein the synthesis and characterization of two new dinuclear iron complexes $\left[\left(\mathrm{SO}_{4}\right)(\mathrm{L} 5) \mathrm{Fe}(\mu-\mathrm{O}) \mathrm{Fe}(\mathrm{L} 5)\right.$ $\left.\left(\mathrm{SO}_{4}\right)\right] \cdot 6 \mathrm{H}_{2} \mathrm{O}, \mathbf{1}$, and $[\mathrm{Cl}(\mathrm{L} 5) \mathrm{Fe}(\mu-\mathrm{O}) \mathrm{Fe}(\mathrm{L} 5) \mathrm{Cl}] \mathrm{Cl}_{2} \cdot 2 \mathrm{H}_{2} \mathrm{O}$, 2 , which were synthesized with a new member of the bis(2-pyridylmethyl)amine family: L5 = 1-(bis-pyridin2-ylmethyl-amino)-3-chloropropan-2-ol (Figure 1). An alcohol function was incorporated into this ligand aiming to compare its coordination ability with the ligands that possess amide (L3) and carboxylate (L4) groups. Both complexes $\mathbf{1}$ and $\mathbf{2}$ had their catalytic activity in cyclohexane oxidation investigated. The synthesis, molecular structure and nuclease activity of $\mathbf{1}$ have been published previously. ${ }^{21}$
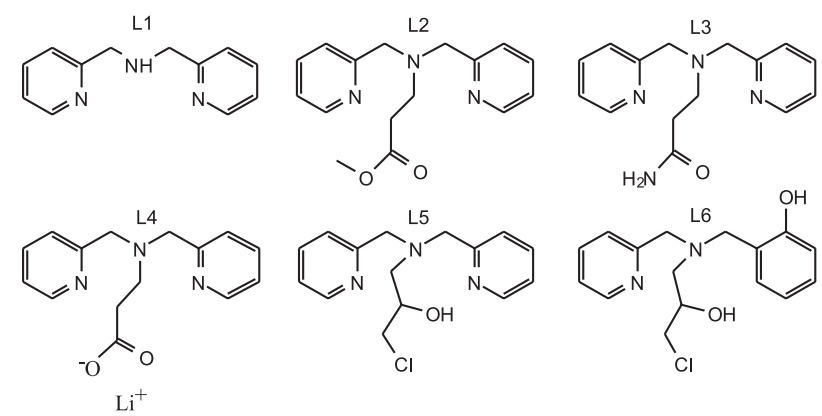

Figure 1. Family of ligands containing the bis(2-pyridylmethyl)amine unit (L1-L5). The structure for ligand L6 is included because it is discussed in the text.

\section{Results and Discussion}

\section{Syntheses}

The complexes were synthesized according to the scheme in Figure 2. During the preparation of 1, a very small amount of a brown solid was formed, which was eliminated by filtration. In the synthesis of $\mathbf{2}$, immediate precipitation of a yellow solid was observed after the addition of the iron salt to the solution containing L5. We tried to isolate this product, but it is highly deliquescent. An initial characterization of this yellow solid, performed by infrared spectroscopy, revealed the absence of Fe-O-Fe stretching, indicating that it might be a mononuclear iron complex. This difficulty, concerning the isolation of a stable solid, 
was solved by refluxing. However, with this procedure, only a red solid could be isolated, characterized as a ( $\mu$-oxo)diiron compound. Interestingly, it was observed that the use of L5 results in dinuclear $\mu$-oxo iron compounds, while the other members of this family (L1-L4) produce mononuclear iron compounds under similar reaction conditions. We have previously published the synthesis of copper and manganese compounds with L5. For these metal ions, only mononuclear compounds were isolated. ${ }^{22,23}$

Both iron complexes are soluble only in polar solvents, including water, $\mathrm{MeOH}, \mathrm{CH}_{3} \mathrm{CN}$, dimethylformamide (DMF) and dimethylsulfoxide (DMSO). Conductivity analysis revealed that both compounds behave as electrolytes in water, indicating that, at least for $\mathbf{1}$ and under the conditions employed, the sulfate group should be displaced from the iron coordination environment.

\section{$X$-ray molecular structure}

The ellipsoid plots of the molecular structure of complexes $\mathbf{1}$ and $\mathbf{2}$ are presented in Figure 3, the main bond distances and angles are shown in Table 1 and the crystallographic data are given in Table 2 .

The molecular structure of $\mathbf{1}$ has been published previously. Compound $\mathbf{1}$ shows a neutral dinuclear unit with the iron(III) ions connected by a $\mu$-oxo bridge (Fe-O-Fe $\left.=163 \cdot 2(3)^{\circ}\right)$. Each iron(III) ion is also coordinated by one L5 ligand molecule and one monodentate sulfate ion, resulting in a $\mathrm{N}_{3} \mathrm{O}_{3}$ coordination environment around the metal centers.

The bis(2-pyridylmethyl)amine units from the ligand molecules adopt a meridional coordination mode $\left(\mathrm{Fe}-\mathrm{N}_{\text {amine }}\right.$ : average $=2.236 \AA$, Fe- $\mathrm{N}_{\text {py }}$ : average $\left.=2.138 \AA\right)$, with the pyridine groups trans to each other. The same coordination mode was observed in mononuclear copper complexes synthesized with L5;22 however, it differs from the mononuclear seven-coordinate manganese compound, in which the pyridine groups are in cis arrangement. ${ }^{23}$

Although it is recognized that the oxo bridge exerts a significant trans effect, it is not very pronounced in $\mathbf{1}$, since the $\mathrm{Fe}-\mathrm{N}_{\text {amine }}$ bond lengths ( $c a .2 .23 \AA$ ) are in the range observed for iron compounds containing tertiary amines cis to the oxo bridge. For example, the Fe- $\mathrm{N}_{\text {amine }}$ bond lengths in the compound $\left[(\text { tpa })(\mathrm{OH}) \mathrm{FeOFe}\left(\mathrm{H}_{2} \mathrm{O}\right)(\mathrm{tpa})\right]^{3+}($ tpa $=$ tris(2-pyridylmethyl)amine) are 2.194(8) $\AA$ when the $\mathrm{N}$ is cis to the oxo bridge and 2.264(8) $\AA$ when it is trans. In the compound $[(\text { tpa }) \mathrm{ClFeOFeCl}(\text { tpa })]^{2+}$, the aliphatic nitrogen atoms are $c i$ s to the oxo bridge and the $\mathrm{Fe}-\mathrm{N}$ bond distances are 2.227(6) $\AA .{ }^{24}$ For the complex [(trispicMeen) $\mathrm{ClFeOFeCl}$ (trispicMeen)], where trispicMeen $=N, N, N^{\prime}-$ tris-(2-pyridylmethyl)- $N^{\prime}$-methylethane-1,2-diamine, the $\mathrm{N}_{\text {amine }}$ trans to the oxo bridge shows an Fe-N bond length of $2.270(16) \AA$, while the $\mathrm{N}_{\text {amine }}$ atoms cis to $\mu$-O the values are 2.243(15) and 2.261(12).${ }^{25}$

In 1 the alcohol groups are located trans to the monodentate sulfate group and cis to the oxo bridge. The Fe- $\mathrm{O}_{\text {alcohol }}$ distances (average: $2.140 \AA$ ) indicate that the alcohol group is protonated. Also, its hydrogen atoms were found from the Fourier difference map. The Fe- $\mathrm{O}_{\text {alcohol }}$ (ca. $2.140 \AA$ ) and Fe- $\mathrm{N}_{\text {pyridine }}(2.138 \AA$ ) bond lengths are very similar, indicating that, at least in terms of structural parameters, both groups have similar basicity.

The cation 2 lies on a crystallographic inversion center and, accordingly, it has exact $\mathrm{C}_{\mathrm{i}}$ local symmetry, which gives the chloride ions an anti configuration, similar to that observed in the compound [(tpa) $\mathrm{ClFeOFeCl}(\mathrm{tpa})]^{2+}{ }^{24}$ In complex 1, in its turn, the sulfate groups show a syn configuration. The L5 coordination mode also differs significantly from that observed in $\mathbf{1}$. In $\mathbf{1}$ the $\mathrm{N}_{\text {amine }}$ atoms are trans to the oxo bridge, while in $\mathbf{2}$ the alcohol groups occupy this position. In contrast, the $\mathrm{N}_{\text {amine }}$ in $\mathbf{2}$ is cis to the oxo bridge, with Fe- $\mathrm{N}_{\text {amine }}$ distances of 2.191(3) $\AA$. The pyridyl groups are positioned trans to each other, as observed in $\mathbf{1}$.

In 2 , the $\mathrm{Fe}-\mathrm{O}-\mathrm{Fe}$ unit is linear, which makes the $\mathrm{Fe} \cdot \cdots \mathrm{Fe}$ distance (3.580(5) ̊) slightly longer than in 1 (3.5323(13) $\mathrm{A})$. The oxo bridge in $\mathbf{2}$ shows a more pronounced trans effect when compared with $\mathbf{1}$, resulting in a $\mathrm{Fe}-\mathrm{O}_{\text {alcohol }}$ bond length of 2.241(2) $\AA$. This bond distance was approximately $2.140 \AA$ in $\mathbf{1}$, with the alcohol coordinated cis to the oxo bridge. Curiously, although there are different groups trans to the oxo bridge in $\mathbf{1}$ (amine) and $\mathbf{2}$ (alcohol), the bond lengths are practically the same: 2.236(5) in $\mathbf{1}$ and 2.241(2) $\AA$ in $\mathbf{2}$. The Fe-N bond lengths in $\mathbf{2}$ are slightly shorter than in $\mathbf{1}$.
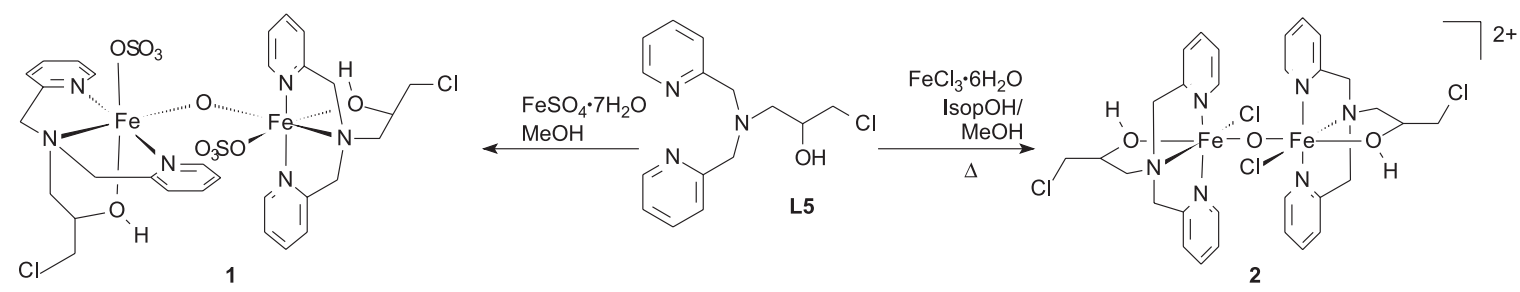

Figure 2. Synthesis of compounds $\mathbf{1}$ and $\mathbf{2}$. 
Both isomeric forms of the ligand are observed in $\mathbf{2}(R$ around Fe1i and $S$ around $\mathrm{Fe} 1$ ), while only the $R$ isomer is present in $\mathbf{1}$.

We have previously reported the coordination behavior of a similar ligand $\{N$-(2-hydroxybenzyl)- $N$-(2-pyridylmethyl) [(3-chloro)(2-hydroxy)] propylamine\} (L6 in Figure 1) which differs from $\mathrm{L} 5$ by the presence of one pyridine and one phenol group instead of two pyridines as observed in L5. L6 forms a mononuclear compound when it reacts with $\mathrm{FeCl}_{3} \cdot 6 \mathrm{H}_{2} \mathrm{O},{ }^{8}$ while dinuclear iron complexes were obtained by reactions with $\mathrm{FeSO}_{4} \cdot 7 \mathrm{H}_{2} \mathrm{O}$ and $\mathrm{Fe}\left(\mathrm{ClO}_{4}\right)_{3} \cdot 9 \mathrm{H}_{2} \mathrm{O}$. The structural characterization of the dinuclear complexes synthesized with L6, $\left[\mathrm{Fe}_{2}(\mathrm{~L} 6)_{2}\left(\mathrm{H}_{2} \mathrm{O}\right)_{2}\right]^{2+},\left[\mathrm{Fe}_{2}(\mathrm{~L} 6)_{2}(\mathrm{OAc})\right]^{+}$ and $\left[\mathrm{Fe}_{2}(\mathrm{~L} 6)_{2}\left(\mathrm{SO}_{4}\right)\right],{ }^{26}$ revealed that the iron ions are bridged by alkoxide groups from the ligand instead of presenting an oxo bridge, as observed for $\mathbf{1}$ and $\mathbf{2}$.
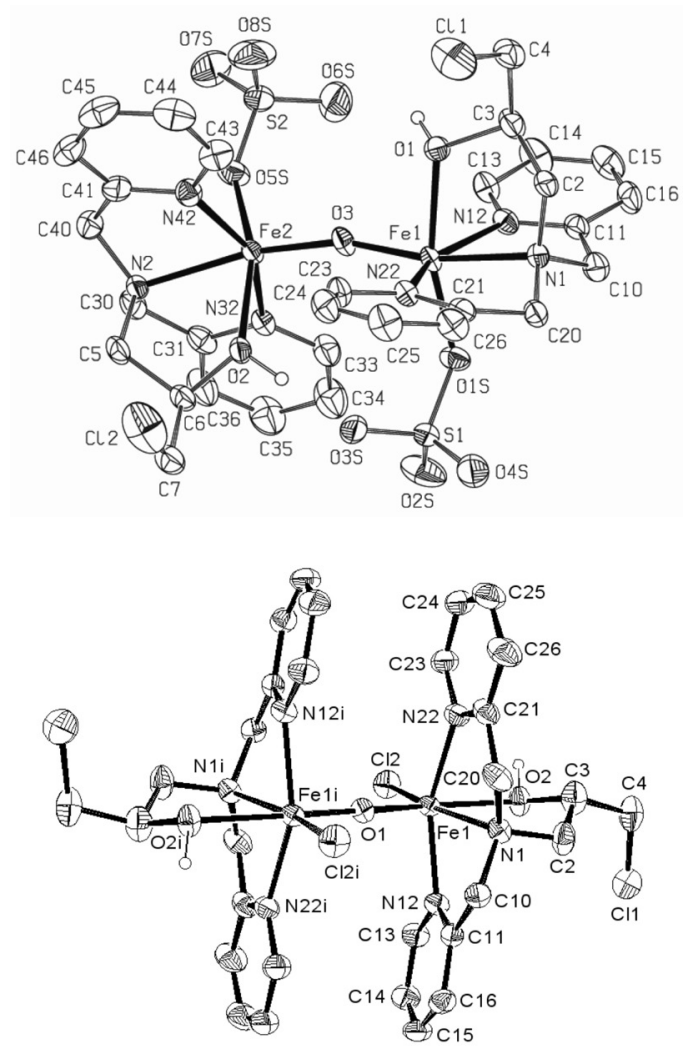

Figure 3. ORTEP diagrams for $\mathbf{1}$ (top) and $\mathbf{2}$ (bottom) with thermal ellipsoids at $40 \%$ probability. Hydrogen atoms and solvates are omitted for clarity. Symmetry code for $2:-\mathrm{x},-\mathrm{y},-\mathrm{z}+1$.

\section{Spectroscopic and electrochemical characterization}

The infrared spectra of the complexes are very similar, with the major difference being related to the presence of sulfate groups in 1, resulting in bands at 1175, 1124, 1106 and $1036 \mathrm{~cm}^{-1}$. Bands characteristic of pyridine groups are observed at 1610,1573, 1487 and $1449 \mathrm{~cm}^{-1}$,
Table 1. Selected bond lengths and angles for complexes $\mathbf{1}$ and $\mathbf{2}$

\begin{tabular}{|c|c|c|c|}
\hline \multirow{2}{*}{$\begin{array}{l}\text { Complex } 1 \\
\text { Fe1-O3 }\end{array}$} & \multicolumn{3}{|c|}{ Bond lengths $(\AA)$} \\
\hline & $1.777(4)$ & $\mathrm{Fe} 2-\mathrm{O} 3$ & $1.793(4)$ \\
\hline $\mathrm{Fe} 1-\mathrm{O} 1 \mathrm{~S}$ & $1.961(4)$ & $\mathrm{Fe} 2-\mathrm{O} 5 \mathrm{~S}$ & $1.958(4)$ \\
\hline $\mathrm{Fe} 1-\mathrm{N} 12$ & $2.140(5)$ & Fe2-N32 & $2.120(5)$ \\
\hline $\mathrm{Fe} 1-\mathrm{O} 1$ & $2.144(4)$ & $\mathrm{Fe} 2-\mathrm{O} 2$ & $2.135(4)$ \\
\hline $\mathrm{Fe} 1-\mathrm{N} 22$ & $2.145(5)$ & $\mathrm{Fe} 2-\mathrm{N} 42$ & $2.146(6)$ \\
\hline \multirow[t]{2}{*}{$\underline{\text { Fe1-N1 }}$} & $2.235(5)$ & $\mathrm{Fe} 2-\mathrm{N} 2$ & $2.237(5)$ \\
\hline & \multicolumn{3}{|c|}{ Angles $\left({ }^{\circ}\right)$} \\
\hline O3-Fe1-O1S & $104.6(2)$ & O3-Fe2-O5S & 108.71(19) \\
\hline O3-Fe1-N12 & $103.7(2)$ & O3-Fe2-N32 & $105.0(2)$ \\
\hline O1S-Fe1-N12 & $86.96(19)$ & O5S-Fe2-N32 & 87.1(2) \\
\hline O3-Fe1-O1 & $90.58(18)$ & $\mathrm{O} 3-\mathrm{Fe} 2-\mathrm{O} 2$ & $89.78(18)$ \\
\hline O1S-Fe1-O1 & $163.84(18)$ & $\mathrm{O} 5 \mathrm{~S}-\mathrm{Fe} 2-\mathrm{O} 2$ & $161.20(18)$ \\
\hline N12-Fe1-O1 & $84.06(19)$ & N32-Fe2-O2 & $84.72(19)$ \\
\hline O3-Fe1-N22 & $103.89(19)$ & O3-Fe2-N42 & $102.2(2)$ \\
\hline O1S-Fe1-N22 & $93.02(19)$ & O5S-Fe2-N42 & $88.4(2)$ \\
\hline N12-Fe1-N22 & $151.5(2)$ & N32-Fe2-N42 & $152.4(2)$ \\
\hline O1-Fe1-N22 & $88.56(18)$ & $\mathrm{O} 2-\mathrm{Fe} 2-\mathrm{N} 42$ & 91.04(19) \\
\hline O3-Fe1-N1 & $167.0(2)$ & $\mathrm{O} 3-\mathrm{Fe} 2-\mathrm{N} 2$ & $165.05(19)$ \\
\hline O1S-Fe1-N1 & $88.38(19)$ & O5S-Fe2-N2 & $86.11(19)$ \\
\hline N12-Fe1-N1 & 76.53(19) & N32-Fe2-N2 & $76.9(2)$ \\
\hline O1-Fe1-N1 & $76.48(17)$ & $\mathrm{O} 2-\mathrm{Fe} 2-\mathrm{N} 2$ & $75.55(17)$ \\
\hline $\mathrm{N} 22-\mathrm{Fe} 1-\mathrm{N} 1$ & $75.00(19)$ & $\mathrm{N} 42-\mathrm{Fe} 2-\mathrm{N} 2$ & $75.7(2)$ \\
\hline Complex 2 & \multicolumn{3}{|c|}{ Bond lengths $(\AA)$} \\
\hline $\mathrm{Fe} 1-\mathrm{O} 1$ & $1.7897(5)$ & Fe1-N1 & 2.191(3) \\
\hline Fe1-N12 & 2.121(3) & $\mathrm{Fe} 1-\mathrm{O} 2$ & $2.241(2)$ \\
\hline \multirow[t]{2}{*}{$\mathrm{Fe} 1-\mathrm{N} 22$} & $2.123(3)$ & $\mathrm{Fe} 1-\mathrm{Cl} 2$ & $2.2758(9)$ \\
\hline & \multicolumn{3}{|c|}{ Angles $\left({ }^{\circ}\right)$} \\
\hline O1-Fe1-N12 & $92.69(8)$ & N22-Fe1-O2 & $82.69(11)$ \\
\hline O1-Fe1-N22 & $92.79(8)$ & $\mathrm{N} 1-\mathrm{Fe} 1-\mathrm{O} 2$ & $76.28(10)$ \\
\hline N12-Fe1-N22 & $153.88(12)$ & $\mathrm{O} 1-\mathrm{Fe} 1-\mathrm{Cl} 2$ & 104.59(3) \\
\hline O1-Fe1-N1 & $92.60(8)$ & $\mathrm{N} 12-\mathrm{Fe} 1-\mathrm{Cl} 2$ & $100.93(8)$ \\
\hline N12-Fe1-N1 & $76.27(11)$ & $\mathrm{N} 22-\mathrm{Fe} 1-\mathrm{Cl} 2$ & $102.35(9)$ \\
\hline N22-Fe1-N1 & $77.99(12)$ & N1-Fe1-Cl2 & $162.74(8)$ \\
\hline O1-Fe1-O2 & $168.63(7)$ & $\mathrm{O} 2-\mathrm{Fe} 1-\mathrm{Cl} 2$ & $86.60(7)$ \\
\hline $\mathrm{N} 12-\mathrm{Fe} 1-\mathrm{O} 2$ & $87.03(11)$ & Fe1-O1-Fe1i & $180.00(5)$ \\
\hline
\end{tabular}

and of the alcohol group at $3450 \mathrm{~cm}^{-1}$. The asymmetric stretching of the oxo bridge $\left(v_{\text {as }} \mathrm{Fe}-\mathrm{O}-\mathrm{Fe}\right)$ gives rise to a band of medium intensity at 832 for $\mathbf{1}$ and $825 \mathrm{~cm}^{-1}$ for $\mathbf{2}$, presenting higher wavenumber values when compared with $[(\text { tpa }) \mathrm{ClFeOFeCl}(\text { tpa })]^{2+}\left(v_{\text {as }}=816 \mathrm{~cm}^{-1}\right) .^{24}$

The Mössbauer spectra of the complexes were collected at room temperature (Figure 4). The spectra for both complexes consist of a single quadrupole doublet, indicating the presence of only one type of iron 
Table 2. Crystal data and structure refinement for complexes $\mathbf{1}$ and $\mathbf{2}$

\begin{tabular}{|c|c|c|}
\hline & Complex 1 & Complex 2 \\
\hline Empirical formula & $\mathrm{C}_{30} \mathrm{H}_{48} \mathrm{Cl}_{2} \mathrm{Fe}_{2} \mathrm{~N}_{6} \mathrm{O}_{17} \mathrm{~S}_{2}$ & $\mathrm{C}_{30} \mathrm{H}_{40} \mathrm{Cl}_{6} \mathrm{Fe}_{2} \mathrm{~N}_{6} \mathrm{O}_{5}$ \\
\hline Formula weight & 1011.46 & 889.08 \\
\hline Temperature $(\mathrm{K})$ & 293(2) & 293(2) \\
\hline Wavelength $(\AA)$ & 0.71073 & 0.71073 \\
\hline Crystal system & Monoclinic & Triclinic \\
\hline Space group & $\mathrm{P} 2 / \mathrm{c}$ & $\mathrm{P} \overline{1}$ \\
\hline \multicolumn{3}{|l|}{ Unit cell dimensions } \\
\hline $\mathrm{a}(\AA)$ & 19.104(4) & $8.4405(7)$ \\
\hline $\mathrm{b}(\AA)$ & 15.071(3) & $10.2902(12)$ \\
\hline c $(\AA)$ & $16.826(3)$ & $12.4575(16)$ \\
\hline$\alpha\left(^{\circ}\right)$ & & $66.714(3)$ \\
\hline$\beta\left(^{\circ}\right)$ & 108.81(3) & $84.629(3)$ \\
\hline$\gamma\left({ }^{\circ}\right)$ & & $72.324(3)$ \\
\hline Volume $\left(\AA^{3}\right)$ & $4585.6(16)$ & $946.50(18)$ \\
\hline $\mathrm{Z}$ & 4 & 1 \\
\hline Density (calc.) $\left(\mathrm{Mg} / \mathrm{m}^{3}\right)$ & 1.465 & 1.560 \\
\hline$\mu\left(\mathrm{mm}^{-1}\right)$ & 0.911 & 1.236 \\
\hline $\mathrm{F}(000)$ & 2096 & 456 \\
\hline Crystal size $\left(\mathrm{mm}^{3}\right)$ & $0.40 \times 0.26 \times 0.23$ & $0.24 \times 0.18 \times 0.10$ \\
\hline Theta range $\left(^{\circ}\right)$ & 1.13 to 25.08 & 3.56 to 26.05 \\
\hline Index ranges & $-22 \leq \mathrm{h} \leq 0 ; 0 \leq \mathrm{k} \leq 17 ;-18 \leq 1 \leq 20$ & $-10 \leq \mathrm{h} \leq 10 ;-12 \leq \mathrm{k} \leq 12 ;-15 \leq 1 \leq 15$ \\
\hline Reflections collected & 8380 & 10816 \\
\hline Independent reflections & $8124[\mathrm{R}(\mathrm{int})=0.0249]$ & $3709[\mathrm{R}(\mathrm{int})=0.0227]$ \\
\hline Absorption correction & Psi-scan & Multiscan \\
\hline Transmission factors & 0.808 and 0.769 & 0.886 and 0.756 \\
\hline Refinement method & Full-matrix least-squares on $\mathrm{F}^{2}$ & Full-matrix least-squares on $\mathrm{F}^{2}$ \\
\hline Data / parameters & $8124 / 502$ & $3709 / 233$ \\
\hline Goodness-of-fit on $\mathrm{F}^{2}$ & 1.090 & 1.053 \\
\hline$R$ indices $[I>2 \sigma(I)]$ & $\mathrm{R}_{1}=0.0681, \mathrm{wR}_{2}=0.1985$ & $\mathrm{R}_{1}=0.0488, \mathrm{wR}_{2}=0.1272$ \\
\hline$\underline{\mathrm{R} \text { indices (all data) }}$ & $\mathrm{R}_{1}=0.1387, \mathrm{wR}_{2}=0.2171$ & $\mathrm{R}_{1}=0.0594, \mathrm{wR}_{2}=0.1329$ \\
\hline
\end{tabular}

nucleus in the solid state for each complex. The observed isomer shifts ( $\delta 0.34$ for $\mathbf{1}$ and $\delta 0.32 \mathrm{~mm} \mathrm{~s}^{-1}$ for 2 ) are characteristic of high spin iron(III). The quadrupole splitting values $\left(\Delta \mathrm{Eq}=1.67\right.$ for $\mathbf{1}$ and $\Delta \mathrm{Eq}=0.98 \mathrm{~mm} \mathrm{~s}^{-1}$ for 2 ) indicate that the iron atoms possess an anisotropic electronic environment. Since high spin $\mathrm{Fe}^{\mathrm{III}}$ centers show a dependence of $\Delta \mathrm{Eq}$ on the local symmetry and on the electronic environment, ${ }^{27}$ the higher value of $\Delta \mathrm{Eq}$ obtained for compound $\mathbf{1}$ might be related to a less symmetric coordination environment around the iron ions or it might reflect the presence of dianionic sulfate ions, which have a very distinct basicity when compared with the chloride ions coordinated in $\mathbf{2}$.

The electronic spectra of the complexes in $\mathrm{CH}_{3} \mathrm{CN}$ solution are very similar (Figure 5). One band and two shoulders were observed for complex $\mathbf{1}$ and two bands and one shoulder for complex $\mathbf{2}$, all of them located in the UV range and presenting $\varepsilon$ values typical of charge transfer transitions. The band of highest energy is located near $255 \mathrm{~nm}\left(\varepsilon \mathrm{ca} .21 \times 10^{3} \mathrm{dm}^{3} \mathrm{~mol}^{-1} \mathrm{~cm}^{-1}\right)$ for both complexes, and is attributed to ligand-centered transitions (pyridine). The shoulders between 300 and $400 \mathrm{~nm}$ observed in the spectra of $\mathbf{1}$ can be attributed to oxo $\rightarrow \mathrm{Fe}^{\mathrm{III}} \mathrm{LMCT}$ transitions. ${ }^{28}$

Complex 2 also shows a band at $339\left(\varepsilon=6.5 \times 10^{3}\right.$ $\left.\mathrm{dm}^{3} \mathrm{~mol}^{-1} \mathrm{~cm}^{-1}\right)$ and a shoulder near $400 \mathrm{~nm}\left(\varepsilon=3.5 \times 10^{3}\right.$ $\left.\mathrm{dm}^{3} \mathrm{~mol}^{-1} \mathrm{~cm}^{-1}\right)$. Similar bands have also been observed in mononuclear iron compounds containing chloride coordinated to iron(III) ions, and were assigned to LMCT $\mathrm{Cl} \rightarrow \mathrm{Fe}^{\mathrm{III}} .{ }^{18}$ Since complex 2 possesses both oxo and 

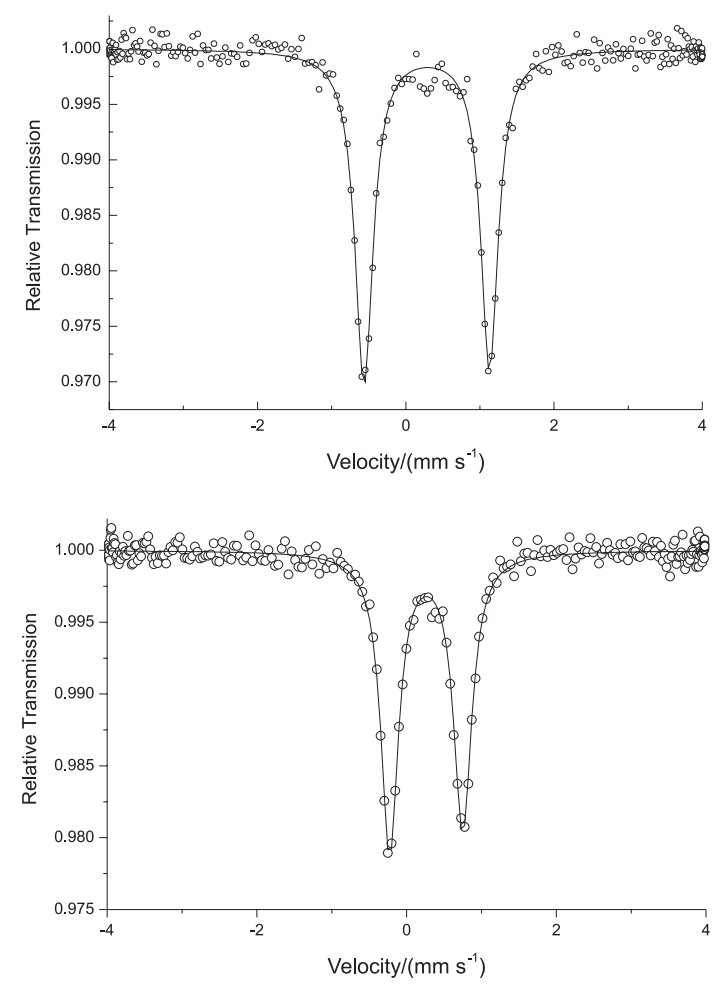

Figure 4. Mössbauer spectra for compounds 1 (top) and 2 (bottom).
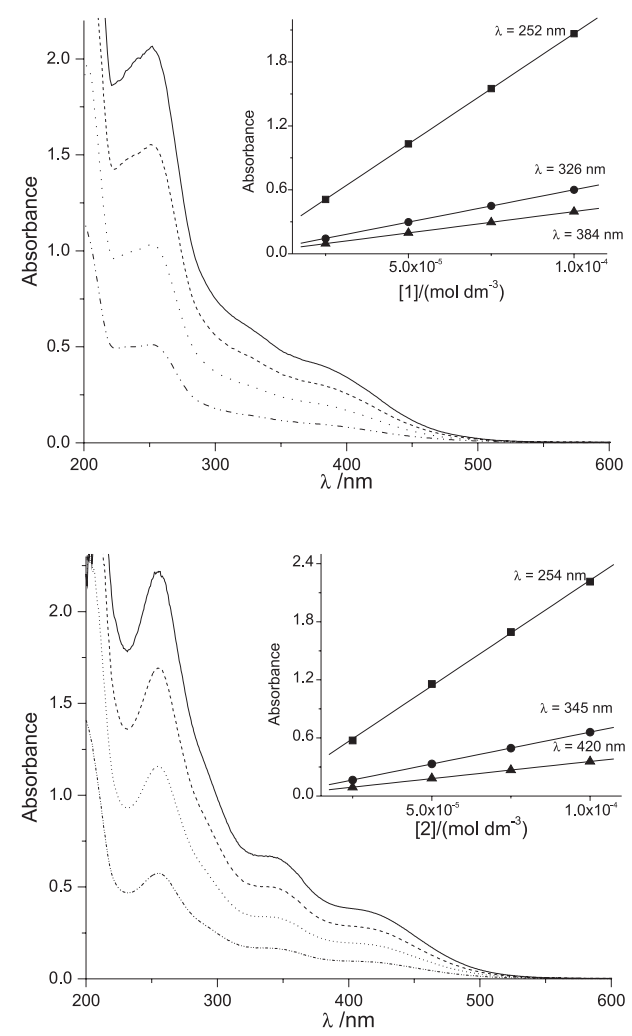

Figure 5. Electronic spectrum of $\mathbf{1}$ (top) and $\mathbf{2}$ (bottom) in acetonitrile at different concentrations: (-) $1.0 \times 10^{-4} ;(---) 7.5 \times 10^{-5} ;(\ldots) 5.0 \times 10^{-5}$ and (..) $2.5 \times 10^{-5} \mathrm{~mol} \mathrm{dm}^{-3} \cdot \lambda(\mathrm{nm}) / \varepsilon\left(\mathrm{dm}^{3} \mathrm{~mol}^{-1} \mathrm{~cm}^{-1}\right): \mathbf{1}=252 / 2.1 \times 10^{4}$; $326 / 6.1 \times 10^{3} ; 384 / 4.0 \times 10^{3} .2=254 / 2.2 \times 10^{4} ; 345 / 6.6 \times 10^{3} ; 420 / 3.5 \times 10^{3}$. The insets show the plots of A versus [complex], used to calculate the $\varepsilon$ values. chloride ligands coordinated to iron(III), it is possible that the absorptions observed between 300 and $450 \mathrm{~nm}$ are composed of LMCT Cl $\rightarrow \mathrm{Fe}^{\mathrm{III}}$ and $\mathrm{oxo} \rightarrow \mathrm{Fe}^{\mathrm{III}}$.

Both complexes show no distinct absorption features in the visible range, which is characteristic of complexes containing linear $\mathrm{Fe}-\mathrm{O}-\mathrm{Fe}$ units. Hence, it is possible to hypothesize that the $\mathrm{Fe}-\mathrm{O}-\mathrm{Fe}$ core in $\mathbf{1}$ might show a linear $\mathrm{Fe}-\mathrm{O}-\mathrm{Fe}$ arrangement in solution, ${ }^{29}$ although in the solid state its angle is $163^{\circ}$.

The cyclic voltammograms of $\mathbf{1}$ and $\mathbf{2}$ are rather distinct (Figure 6). The internal standard $\mathrm{Fc} / \mathrm{Fc}^{+}$is observed at $0.418 \mathrm{~V}$ $\left(\Delta \mathrm{E}_{\mathrm{p}}=125 \mathrm{mV}\right)$, and the free L5 base does not show any electrochemical process between -1.8 to $1.0 \mathrm{~V}$.

Compound 1 shows two quasi-reversible redox processes at $-0.690\left(\Delta \mathrm{E}_{\mathrm{p}}=0.151 \mathrm{~V}\right)$ and $-1.30 \mathrm{~V}\left(\Delta \mathrm{E}_{\mathrm{p}}=0.222 \mathrm{~V}\right)$ associated with the redox couples $\mathrm{Fe}^{\mathrm{III}} \mathrm{Fe}^{\mathrm{III}} / \mathrm{Fe}^{\mathrm{III}} \mathrm{Fe}^{\mathrm{II}}$ and $\mathrm{Fe}^{\mathrm{II}} \mathrm{Fe}^{\mathrm{II}} / \mathrm{Fe}^{\mathrm{II}} \mathrm{Fe}^{\mathrm{II}}$. Furthermore, it is possible to see another oxidation wave at $-0.322 \mathrm{~V}$ versus $\mathrm{Fc} / \mathrm{Fc}^{+}$, which means that the anodic wave for the first redox process, observed at $-0.690 \mathrm{~V} v s . \mathrm{Fc} / \mathrm{Fc}^{+}$, is associated with two oxidative processes. A similar behavior has been observed for the compound $\left[\right.$ (trispicMeen) $\mathrm{ClFe}^{\mathrm{m}} \mathrm{OFe}{ }^{\mathrm{mI}} \mathrm{Cl}(\text { trispicMeen) }]^{2+},{ }^{25}$ for which the anodic process for the first redox couple was composed of two oxidation waves attributed to the presence of two species in equilibrium, a six and a five coordinated $\mathrm{Fe}^{\mathrm{II}}$. Since a similar feature is observed in the cyclic voltammogram of $\mathbf{1}$, the presence of two species in equilibrium can be proposed. Thus, after the first process of reduction, the sulfate anion possibly leaves the coordination environment of the iron center and six and five coordinated iron(II) ions coexist on the electrode surface, resulting in the two anodic processes.

The cyclic voltammogram of $\mathbf{2}$ shows two very well defined irreversible processes, one cathodic at -0.426 and another anodic at $-0.223 \mathrm{~V}$ versus $\mathrm{Fc} / \mathrm{Fc}^{+}$. There is a second irreversible cathodic process with low current intensity at $-0.826 \mathrm{~V} v s$. Fc $/ \mathrm{Fc}^{+}$. The electrochemical profile presented by 2 is similar to that reported by Costes and co-workers. ${ }^{30}$ For (L) $\mathrm{Fe}-\mathrm{O}-\mathrm{Fe}(\mathrm{L})$ compounds, where $\mathrm{L}$ is a Schiff base, Costes suggested that, after the first step of reduction - which leads to the formation of the mixed valence $\mathrm{Fe}^{\mathrm{III}} \mathrm{Fe}^{\mathrm{II}}$ - the dinuclear unit is broken, resulting in mononuclear species that are oxidized at a more positive potential. Thus, it is possible to hypothesize that there is a chemical reaction associated with the reduction process of $\mathbf{2}$ at $-0.426 \mathrm{~V}$, resulting in the breaking of the dinuclear unit and formation of mononuclear species. This explains why the electrochemical behavior of $\mathbf{2}$ is so distinct from that of $\mathbf{1}$. The presence of a second cathodic process with low current intensity may suggest that a small amount of the dinuclear unit remains on the electrode surface.

The anodic process observed at $-0.223 \mathrm{~V}$ is related to the oxidation of the mononuclear iron(II) species 
electrochemically formed on the electrode surface. The formation of this mononuclear species is also supported by the fact that the anodic wave at $-0.223 \mathrm{~V}$ is in the range observed for the mononuclear iron compounds containing $\mathrm{L} 1\left(\mathrm{E}_{1 / 2}=\right.$ $-0.347 \mathrm{~V}$ versus $\left.\mathrm{Fc} / \mathrm{Fc}^{+}\right), \mathrm{L} 2\left(\mathrm{E}_{1 / 2}=-0.257 \mathrm{~V}\right.$ versus $\left.\mathrm{Fc} / \mathrm{Fc}^{+}\right)$ and $\mathrm{L} 3\left(\mathrm{E}_{1 / 2}=-0.222 \mathrm{~V}\right.$ versus $\left.\mathrm{Fc} / \mathrm{Fc}^{+}\right)$.

Comparing the molecular structures of $\mathbf{1}$ and $\mathbf{2}$, it is possible to explain their distinct electrochemical behaviors. For 1, the alcohol group bound to one of the iron centers has an orientation that allows it to form a hydrogen bond with the sulfate group bound to the other iron center and/or with the oxo bridge. On the other hand, the alcohol groups present in $\mathbf{2}$ are coordinated trans to the oxo bridge, which does not allow any kind of interaction with the groups coordinated to the second iron center. Thus, the lack of intramolecular hydrogen bonding in $\mathbf{2}$ could lead to the rupture of the dinuclear unit after reduction, while for $\mathbf{1}$ it is proposed that the intramolecular hydrogen bond is responsible for the maintenance of the dinuclear structure.
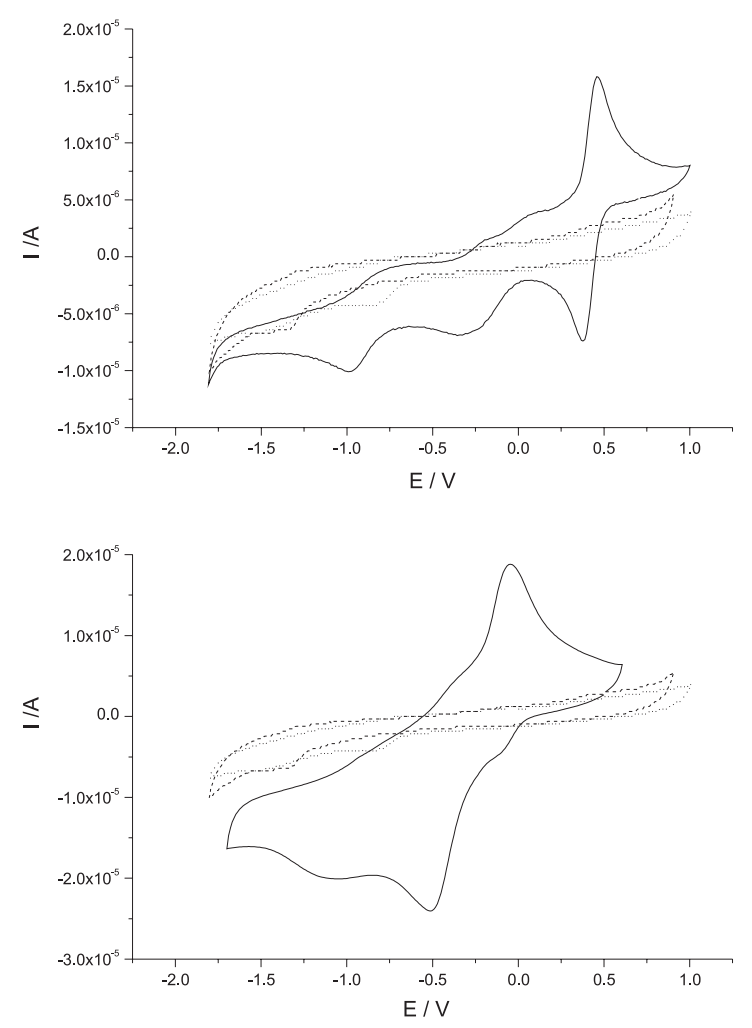

Figure 6. Cyclic voltammograms for compounds $\mathbf{1}$ (top) and $\mathbf{2}$ (bottom) under argon atmosphere. Ferrocene was used as internal standart for complex 1 and as external standart for complex 2. Scan rate: $100 \mathrm{mV} \mathrm{s}^{-1}$. Support electrolyte: $0.1 \mathrm{~mol} \mathrm{dm}^{-3}$ solution of tetrabutylammonium perchlorate in acetonitrile. Pseudo-referene electrode: Pt wire. (----) base line, (‥) ligand, $(-)$ complex

\section{Cyclohexane oxidation}

Since the molecular structures of $\mathbf{1}$ and $\mathbf{2}$ are dinuclear and a dinuclear iron core is present at the methane monooxygenase active site, experiments aiming to evaluate whether the complexes could have monoxygenase activity were carried out. Cyclohexane was employed as the substrate and the reactions were performed employing different solvents $(\mathrm{MeCN} / \mathrm{BuOH})$, oxidants (hydrogen peroxide or tertbutylperoxide) and temperatures $\left(25\right.$ and $\left.50^{\circ} \mathrm{C}\right)$. Cyclohexanol ( $\mathrm{Cy}-\mathrm{OH})$, cyclohexanone $(\mathrm{Cy}=\mathrm{O})$, cyclohexyl hydroperoxide (Cy-OOH), $t$-butyl cyclohexyl peroxide (Cy-OOt-Bu) and adipic acid (AA) were formed during the oxidation process (Scheme 1, Table 3). Control reactions were carried out in the absence of the catalysts and no oxidation products were observed. It is also important to note that the yields reported in Table 3 were based on the substrate, since other kinds of reactions (catalase activity, insertion of oxo groups in the structure of the complexes etc.) may take place.

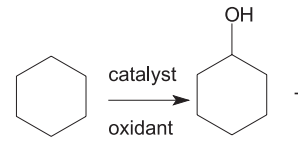

$\mathrm{Cy}-\mathrm{OH}$

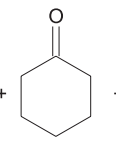

$\mathrm{Cy}=\mathrm{O}$

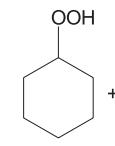

$\mathrm{Cy}-\mathrm{OOH}$

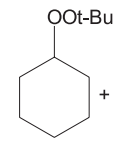

Cy-OOt-Bu

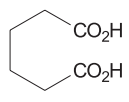

A
Scheme 1. Products observed during cyclohexane oxidation promoted by compounds $\mathbf{1}$ and $\mathbf{2}$. Cy-OH: cyclohexanol; $\mathrm{Cy}=\mathrm{O}$ : cyclohexanone; $\mathrm{Cy}-\mathrm{OOH}$ : cyclohexyl hydroperoxide; $\mathrm{Cy}-\mathrm{OO}^{t}-\mathrm{Bu}$ : tert-butylcyclohexyl peroxide; AA: adipic acid.

At $25^{\circ} \mathrm{C}$, employing acetonitrile as the solvent and $\mathrm{H}_{2} \mathrm{O}_{2}$ as the oxidant (Table 3, entry 1), complex 2 was more active than complex 1. Adipic acid was the main product obtained for complex 2, followed by $\mathrm{Cy}-\mathrm{OOH}, \mathrm{Cy}-\mathrm{OH}$ and $\mathrm{Cy}=\mathrm{O}$. Interestingly, adipic acid is virtually absent when complex $\mathbf{1}$ is used, indicating that the two complexes have different behaviors in promoting the cyclohexane oxidation under these conditions.

Interestingly, when the temperature is raised to $50{ }^{\circ} \mathrm{C}$ (Table 3, entry 2) the total conversions observed for $\mathbf{1}$ and $\mathbf{2}$ are similar. Under this condition, the product adipic acid was not observed, differing significantly from the results obtained at lower temperature, mainly for complex $\mathbf{2}$. For $\mathbf{1}$, the main product obtained is $\mathrm{Cy}-\mathrm{OOH}$, while, for complex $2, \mathrm{Cy}=\mathrm{O}$ was obtained in larger amounts. This suggests that a different oxidation pathway may be in place.

When the oxidant was changed from $\mathrm{H}_{2} \mathrm{O}_{2}$ to $t-\mathrm{BuOOH}$, practically no oxidation was observed at $25^{\circ} \mathrm{C}$ (Table 3, entry 3), but it reaches $19 \%(1)$ and $16 \%(2)$ at $50{ }^{\circ} \mathrm{C}$ (Table 3, entry 4). Under this condition, results indicate the same trend concerning the oxidation products for both complexes, and the major product formed is $\mathrm{Cy}=\mathrm{O}$, which suggests that the catalytic species should be the same for the two precursors. Furthermore, this result reveals that the temperature has an important effect on both the yield and oxidation mechanism. The influence of the temperature was also observed for compound $\mathbf{1}$ when $\mathrm{H}_{2} \mathrm{O}_{2}$ was employed 
as the oxidant (Table 3, entry 1). Entries 3 and 4 indicate that the interaction between the catalysts and the oxidants (mainly for $t-\mathrm{BuOOH}$ ) would not occur so easily at room temperature, probably due to some steric hindrance, since it is facilitated at $50{ }^{\circ} \mathrm{C}$. Thus, it is possible to suggest that, at the higher temperature $\left(50{ }^{\circ} \mathrm{C}\right)$, the coordination environment of the iron center changes (ligand exchange or rupture of the dinuclear unit), facilitating the catalystoxidant interaction, which results in a higher yield for the oxidation reaction.

The change of solvent from acetonitrile to $t \mathrm{BuOH}$ had a negative effect on the total conversion for both temperatures and oxidants. Firstly, we decided to study the cyclohexane oxidation in $t$ - $\mathrm{BuOH}$ due to the fact that both complexes $\mathbf{1}$ and $\mathbf{2}$ are insoluble in this solvent. Thus, a heterogeneous catalysis could take place. However, the addition of the oxidants to the complexes made them soluble, resulting in a homogeneous system. When $\mathrm{H}_{2} \mathrm{O}_{2}$ was used as the oxidant (entries 5 and 6 ) a very low amount of oxidation products were observed at room temperature. However, at $50^{\circ} \mathrm{C}$, complex 2 showed the highest selectivity toward cyclohexanol.

The system $t$ - $\mathrm{BuOOH} / t-\mathrm{BuOH}$ (Table 3, entries 7 and 8) gives reasonable results only at $50{ }^{\circ} \mathrm{C}$ for complex 2 . Under these conditions complex $\mathbf{2}$ showed the highest production and selectivity for $\mathrm{Cy}=\mathrm{O}$.

The two complexes presented here are less effective in promoting cyclohexane oxidation than the mononuclear iron complexes synthesized with the ligands L1-L4 and L6. ${ }^{7,8}$ In contrast to this tendency, $\mathrm{Li}$ and co-workes ${ }^{31}$ reported similar results in the cyclohexane oxidation when the mononuclear $[\mathrm{Fe}$ (tpoen) $\mathrm{Cl}] \mathrm{PF}_{6}$ and the dinuclear $\left[\{\mathrm{Fe}(\text { tpoen })\}_{2}(\mu-\mathrm{O})\right]\left(\mathrm{ClO}_{4}\right)_{4}$ compounds were employed as catalysts (tpoen $=N$-(2-pyridylmethoxyethyl) $-N, N$ bis(2-pyridylmethyl)amine). On the other hand, the dinuclear iron compound $\left[\mathrm{Fe}_{2} \mathrm{OL}_{2}(\mathrm{MeOH})_{2}\left(\mathrm{NO}_{3}\right)_{2}\right]\left(\mathrm{NO}_{3}\right)_{2}$ (L = 2,6-bis $(N$-methylbenzimidazol-2-yl)pyridine) was able to promote the cyclohexane oxidation while the mononuclear iron compound with the same ligand, $\left[\mathrm{FeLCl}_{3}\right]$, was inactive. Compounds $\mathbf{1}$ and $\mathbf{2}$ showed lower activity than the compounds $\left[\{\mathrm{Fe}(\text { tpoen })\}_{2}(\mu-\mathrm{O})\right]\left(\mathrm{ClO}_{4}\right)_{4}$ and $\left[\mathrm{Fe}_{2} \mathrm{OL}_{2}(\mathrm{MeOH})_{2}\left(\mathrm{NO}_{3}\right)_{2}\right]\left(\mathrm{NO}_{3}\right)_{2}$.

Several effects may account for the oxygenase activity of the iron compounds: the redox potential, the lability of the ligands, the presence of ligands able to form hydrogen bonds and steric hindrance effects. ${ }^{32-34}$ The analysis of our data reveals that compounds $\mathbf{1}$ and $\mathbf{2}$ are very distinct catalysts. The activity of each compound is dependent on the experimental conditions (solvent, temperature, oxidant) employed in the oxidation reaction. Since both are dinuclear $\mu$-oxo compounds and contain the same polydentate ligand, the differences observed in the reactivity may be related to the following points: $i$ ) the coordination mode of the polydentate ligand around the iron ions; ii) the charges and types of the monodentate ligands $\left(\mathrm{SO}_{4}^{2-}\right.$ and $\left.\mathrm{Cl}^{-}\right)$; iii) the charges presented by the complexes; iv) the redox potential of the metal center. Since several variables can be related to each other, at the present time it is not possible to establish the factors which drive the activity of the iron complexes synthesized with the ligand L5.

Considering the molecular structure, in compound $\mathbf{2}$ the chloro ligands show an anti configuration to each other, while in 1, the sulfate ions are syn. This structural difference may explain the higher activity of compound $\mathbf{2}$, since the iron centers in this compound are more accessible to the oxidant than those in $\mathbf{1}$. Furthermore, electrochemical data showed that the dinuclear unit in $\mathbf{2}$ is not very stable. Since we have observed previously that the mononuclear iron compounds synthesized with L1L4 and L6 are more active in cyclohexane oxidation than the dinuclear compounds presented here, it is possible that the easier conversion of the dinuclear $\mathbf{2}$ in a mononuclear compound makes this complex a better catalyst that compound $\mathbf{1}$.

\section{Conclusions}

This study revealed that the tripodal tetradentate ligand L5 yields the formation of ( $\mu$-oxo)di-iron(III) compounds. This feature is independent of the oxidation state of the iron salt employed in the synthesis $\left(\mathrm{Fe}^{\mathrm{II}}\right.$ or $\left.\mathrm{Fe}^{\mathrm{III}}\right)$. However, the behaviors related to the coordination mode of the ligand differ, and this accounts for the distinct electrochemical behaviors and probably to the catalytic activities. In general, compound $\mathbf{2}$ was more effective than compound $\mathbf{1}$ in promoting cyclohexane oxidation, although the results for both complexes showed a dependence on the reaction conditions (solvent, oxidant, temperature). The two complexes were more active in the medium with $\mathrm{H}_{2} \mathrm{O}_{2}$ as the oxidant and acetonitrile as the solvent at $50^{\circ} \mathrm{C}$, furnishing the highest turnover values under these conditions. Complexes $\mathbf{1}$ and $\mathbf{2}$ showed lower activity than the mononuclear complexes synthesized with the ligands L1-L4 and L6. The presence of a more labile ligand (chloride), the lower steric hindrance, as well as the higher propensity to form mononuclear compounds observed for compound $\mathbf{2}$, can be considered to explain its higher activity as a catalyst for oxygenation reactions when compared with $\mathbf{1}$.

\section{Experimental}

\section{Materials and methods}

Reagents and solvents were used as received from commercial sources. Only the solvents used for electrochemical and electronic spectroscopy analyses were of spectroscopic grade. L5 was synthesized as described previously.22 
Table 3. Results for the cyclohexane oxidation catalyzed by complexes $\mathbf{1}$ and $\mathbf{2}$ after $24 \mathrm{~h}$

\begin{tabular}{|c|c|c|c|c|c|c|c|c|c|c|c|c|}
\hline \multirow[t]{2}{*}{ Entry } & \multirow[t]{2}{*}{$\mathrm{T}\left({ }^{\circ} \mathrm{C}\right)$} & \multirow[t]{2}{*}{ Oxidant } & \multirow[t]{2}{*}{ Solvent } & \multirow[t]{2}{*}{ Catalyst } & \multicolumn{6}{|c|}{ Yield $(\%)^{\mathrm{a}}$} & \multirow{2}{*}{$\begin{array}{c}\mathrm{Cy}-\mathrm{OH} / \\
\mathrm{Cy}=\mathrm{O}\end{array}$} & \multirow[t]{2}{*}{$\mathrm{TN}^{\mathrm{b}}$} \\
\hline & & & & & $\mathrm{Cy}-\mathrm{OH}$ & $\mathrm{Cy}=\mathrm{O}$ & Сy-OOH & $\mathrm{Cy}-\mathrm{OO} t-\mathrm{Bu}$ & AA & Total & & \\
\hline \multirow[t]{2}{*}{1} & \multirow[t]{2}{*}{$\mathrm{rt}$} & \multirow{2}{*}{$\mathrm{H}_{2} \mathrm{O}_{2}$} & \multirow[t]{2}{*}{$\mathrm{ACN}$} & 1 & 1.0 & - & 5.6 & - & - & 6.6 & & 72 \\
\hline & & & & 2 & 2.9 & 1 & 5.7 & - & 7.7 & 17.3 & 2.9 & 173 \\
\hline \multirow[t]{2}{*}{2} & \multirow[t]{2}{*}{50} & \multirow[t]{2}{*}{$\mathrm{H}_{2} \mathrm{O}_{2}$} & \multirow[t]{2}{*}{$\mathrm{ACN}$} & 1 & 5.4 & 3.5 & 12.6 & - & - & 21.5 & 1.5 & 217 \\
\hline & & & & 2 & 3.9 & 11.2 & 2.8 & - & - & 17.9 & 0.35 & 185 \\
\hline \multirow[t]{2}{*}{3} & \multirow[t]{2}{*}{$\mathrm{rt}$} & \multirow[t]{2}{*}{$t$-BuOOH } & \multirow[t]{2}{*}{$\mathrm{ACN}$} & 1 & 1 & - & - & - & - & 1 & - & 23 \\
\hline & & & & 2 & - & - & - & - & - & - & - & - \\
\hline \multirow[t]{2}{*}{4} & \multirow[t]{2}{*}{50} & \multirow[t]{2}{*}{$t$-BuOOH } & \multirow[t]{2}{*}{$\mathrm{ACN}$} & 1 & 5.9 & 9.4 & 2.2 & 1.4 & - & 18.9 & 0.63 & 191 \\
\hline & & & & 2 & 5.5 & 8.3 & 1.0 & 1.1 & - & 15.9 & 0.66 & 161 \\
\hline \multirow[t]{2}{*}{5} & \multirow[t]{2}{*}{$\mathrm{rt}$} & \multirow[t]{2}{*}{$\mathrm{H}_{2} \mathrm{O}_{2}$} & \multirow[t]{2}{*}{$t-\mathrm{BuOH}$} & 1 & - & - & - & - & - & - & - & - \\
\hline & & & & 2 & - & - & 2.1 & - & 1 & 3.1 & - & 38 \\
\hline \multirow[t]{2}{*}{6} & \multirow[t]{2}{*}{50} & \multirow[t]{2}{*}{$\mathrm{H}_{2} \mathrm{O}_{2}$} & \multirow[t]{2}{*}{$t-\mathrm{BuOH}$} & 1 & 1 & - & 1.2 & - & - & 2.2 & - & 27 \\
\hline & & & & 2 & 5.6 & 2.9 & - & - & 1 & 9.5 & 1.9 & 92 \\
\hline \multirow[t]{2}{*}{7} & \multirow[t]{2}{*}{$\mathrm{rt}$} & $t$-BuOOH & $t-\mathrm{BuOH}$ & 1 & - & - & - & - & - & - & - & - \\
\hline & & & & 2 & - & - & - & - & 6.8 & 6.8 & - & 73 \\
\hline 8 & 50 & $t-\mathrm{BuOOH}$ & $t-\mathrm{BuOH}$ & 1 & 1.4 & 1.5 & 1.9 & - & - & 4.8 & 0.9 & 55 \\
\hline & & & & 2 & 2.6 & 11.6 & - & 2.3 & - & 16.5 & 0.22 & 167 \\
\hline
\end{tabular}

${ }^{a}$ Yields were calculated in relation to the substrate, using the equation (1), which relates the yield calculated from chromatographic analysis and the yield calculated from titration. For the chromatographic yield, the equations (2) and (3) were employed, using the corrected areas of the products (considering the corresponding response factor). ${ }^{b} \mathrm{TN}$, turnover number; calculated as mol of products per mol of catalyst. $R_{t}=R_{A A}+R_{r c}(1)$, where $R_{t}=$ total yield; $R_{A A}=$ yield of adipic acid obtained from titration; $R_{r c}=$ corrected chromatographic yield; $R_{r c}=\frac{R_{c} \times n_{c}}{n_{t}}(2)$, where $\mathrm{R}_{\mathrm{c}}=$ chromatographic yield; $n_{\mathrm{c}}=$ number of moles analyzed by GC $\left(\mathrm{n}_{\mathrm{c}}=n_{t}-n_{a a} ; n_{a a}=\right.$ mols of adipic acid; $n_{\mathrm{t}}=$ number of moles of substrate); $R_{c}=\frac{A_{p}}{A_{t}} \times 100$ (3), where $\mathrm{A}_{p}=$ corrected area of the products from GC; $\mathrm{A}_{t}=$ total corrected area (sum of the areas of products and substrate from GC).

UV-Vis spectra were recorded on a Shimadzu 1601PC UV-Vis spectrophotometer in acetonitrile. Infrared spectra were collected on a FTIR Nicolet Magna-IR 760 spectrophotometer, with the sample dispersed in KBr. Mössbauer spectra were obtained using a Wissel instrument in the constant acceleration mode with transmission geometry. A ${ }^{57} \mathrm{Co} / \mathrm{Rh}$ source was maintained at room temperature. The resultant spectra were least-squares fitted to Lorentzian shaped lines using the NORMOS software (Wissel Company). Metallic iron was used for energy calibration and also as a reference for the isomer shift $(\delta)$ scale. Conductivity measurements were carried out with solutions containing $1 \times 10^{-3} \mathrm{~mol} \mathrm{dm}^{-3}$ of the complexes, using a BioCristal NT CVM conductivimeter, employing a conductivity cell CA150. Cyclic voltammetry experiments were carried out using an Autolab PGSTAT10 potentiostat/galvanostat and a three electrode system, with a glassy carbon disk as the working electrode, a platinum wire as the auxiliary electrode and a platinum wire as the pseudo-reference electrode. As the supporting electrolyte, a $0.1 \mathrm{~mol} \mathrm{dm}^{-3}$ solution of tetrabutylammonium perchlorate in acetonitrile was used. The redox couple $\mathrm{Fc} / \mathrm{Fc}^{+}(0.400 \mathrm{~V}$ versus $\mathrm{NHE}$ ) was used as the internal standard ${ }^{35}$ Cyclohexane was purified before handling through successive extractions with $\mathrm{H}_{2} \mathrm{SO}_{4}, \mathrm{H}_{2} \mathrm{O}$ and $\mathrm{NaHCO}_{3}$ solution (1\%), respectively, and distilled over $\mathrm{CaH}_{2}$. The oxidants, $\mathrm{H}_{2} \mathrm{O}_{2}$ and tert-butyl hydroperoxide $(t-\mathrm{BuOOH})$, were titrated using the iodometric method. The oxidation products were analyzed in an HP 5890 gas chromatographer with FID detector and a DB-5 column.

\section{Synthesis of $\left[\left(\mathrm{SO}_{4}\right)(\mathrm{L} 5) \mathrm{Fe}(\mu-\mathrm{O}) \mathrm{Fe}(\mathrm{L} 5)\left(\mathrm{SO}_{4}\right)\right] \cdot 6 \mathrm{H}_{2} \mathrm{O}(\mathrm{I})$}

This complex was obtained through the reaction of a methanolic solution $\left(50 \mathrm{~cm}^{3}\right)$ of $\mathrm{L} 5(2 \mathrm{mmol}, 0.58 \mathrm{~g})$ followed by the addition of an equimolar amount of solid $\mathrm{FeSO}_{4} \cdot 7 \mathrm{H}_{2} \mathrm{O}$ $(0.56 \mathrm{~g})$. The solution acquired immediately a greenish-brown color. The reaction mixturewas stirred for one hour, filtered and left to stand. The next day a red microcrystalline material began to precipitate. After 3 days, this microcrystalline solid was filtered, washed with cold propan-2-ol and dried under vacuum $(0.48 \mathrm{~g}, 48 \%)$. Found: C, 33.95; H, 4.9; N, 7.6; $\mathrm{C}_{30} \mathrm{H}_{36} \mathrm{Cl}_{2} \mathrm{Fe}_{2} \mathrm{~N}_{6} \mathrm{O}_{11} \mathrm{~S}_{2} \cdot 9 \mathrm{H}_{2} \mathrm{O}$ requires $\mathrm{C}, 33.8 ; \mathrm{H}, 5.1 ; \mathrm{N}, 7.9 \%$. $\operatorname{IR}(\mathrm{KBr}) v_{\text {max }} / \mathrm{cm}^{-1}: 3463(\mathrm{OH}), 1610,1573,1487,1449(\mathrm{C}=\mathrm{C}$, $\mathrm{C}=\mathrm{N}$, pyridine), 1175, 1124, 1106, $1036\left(\mathrm{SO}_{4}\right), 832$ ( $\left.\mathrm{Fe}-\mathrm{O}-\mathrm{Fe}\right)$. $\Lambda_{\mathrm{M}}=22.7 \mathrm{~cm}^{2} \Omega^{-1} \mathrm{~mol}^{-1}$ (DMF: no electrolyte). ${ }^{36}$ This solid was recrystallized in $\mathrm{MeOH}$, rendering red diamond shaped crystals suitable for $\mathrm{X}$-ray analysis.

Synthesis of $[\mathrm{Cl}(\mathrm{L} 5) \mathrm{Fe}(\mu-\mathrm{O}) \mathrm{Fe}(\mathrm{L} 5) \mathrm{Cl}] \mathrm{Cl}_{2} \cdot 2 \mathrm{H}_{2} \mathrm{O}(2)$ $2 \mathrm{mmol}(0.58 \mathrm{~g})$ of $\mathrm{L} 5$ were dissolved in $20 \mathrm{~cm}^{3}$ of propan- 
2-ol, followed by the addition of a solution (propan-2-ol, $20 \mathrm{~cm}^{3}$ ) containing an equimolar amount of $\mathrm{FeCl}_{3} \cdot 6 \mathrm{H}_{2} \mathrm{O}$. A yellow solid was immediately formed. Methanol $\left(50 \mathrm{~cm}^{3}\right)$ was added and the solution was refluxed for $1.5 \mathrm{~h}$, rendering an orange solution. This solution was kept at room temperature, and after four days red single crystals suitable for X-ray analysis were isolated $(0.39 \mathrm{~g}, 44 \%)$. Found: $\mathrm{C}=40.5 ; \mathrm{H}=4.4$; $\mathrm{N}, 9.3 ; \mathrm{C}_{30} \mathrm{H}_{36} \mathrm{Cl}_{6} \mathrm{Fe}_{2} \mathrm{~N}_{6} \mathrm{O}_{3} \cdot 2 \mathrm{H}_{2} \mathrm{O}$ requires $\mathrm{C}=40.5 ; \mathrm{H}=4.5$; $\mathrm{N}=9.45$. IR $(\mathrm{KBr}) v_{\max } / \mathrm{cm}^{-1}: 3421(\mathrm{OH}), 1607,1570$, 1483, 1445 ( $\mathrm{C}=\mathrm{C}, \mathrm{C}=\mathrm{N}$, pyridine $), 825$ ( $\mathrm{Fe}-\mathrm{O}-\mathrm{Fe})$. $\Lambda_{\mathrm{M}}=147.8 \mathrm{~cm}^{2} \Omega^{-1} \mathrm{~mol}^{-1}$ (DMF: $2: 1$ electrolyte type). ${ }^{36}$

\section{Crystallographic analysis}

Crystallographic analysis was carried out on a CAD-4 diffractometer for complex 1 and on an APEX II diffractometer for complex 2, at room temperature. For complex $\mathbf{1}$, the electronic density attributed to highly disordered solvent molecules was removed using squeeze correction with PLATON. ${ }^{37}$ All non-hydrogen atoms were refined with anisotropic displacement parameters, except for the oxygen atoms of the six water molecules of crystallization. Hydrogen atoms attached to carbon atoms were fixed at their idealized positions, whereas the $\mathrm{H}$ atoms of the alcohol groups were found from the Fourier map and treated with a riding model. The hydrogen atoms for the water molecules were not found. For complex 2, all non-hydrogen atoms were refined anisotropically. The counterion chloride $(\mathrm{Cl} 3)$ is disordered over two alternative positions, with refined occupancy of $0.52(5)$ and $0.48(5)$. H atoms of the alcohol group and of the water molecule were found from the Fourier map and also treated with a riding model. Other $\mathrm{H}$ atoms were placed at their idealized positions, with $\mathrm{C}-\mathrm{H}$ distances and $\mathrm{U}_{\text {eq }}$ values taken from the default settings of the refinement program. Further crystallographic information is given in Table 2.

\section{Cyclohexane oxidation}

The reactions were carried out in a $50 \mathrm{~cm}^{3}$ round bottom flask under stirring for $24 \mathrm{~h}$. Different solvents, temperatures and oxidants were employed, using an experimental optimization method. The catalyst:substrate:oxidant ratio was 1:1000:1000. The reagent amounts were: $0.75 \mathrm{~cm}^{3}$ of cyclohexane $\left(7 \times 10^{-3} \mathrm{~mol}\right), 0.59 \mathrm{~cm}^{3}$ of $\mathrm{H}_{2} \mathrm{O}_{2}$ or $0.93 \mathrm{~cm}^{3}$ of $t$-BuOOH $\left(7 \times 10^{-3} \mathrm{~mol}\right), 7.4 \mathrm{mg}$ of 1 or $6.0 \mathrm{mg}$ of 2 $\left(7 \times 10^{-6} \mathrm{~mol}\right)$. Acetonitrile $(\mathrm{MeCN})$ and $t$-butanol $(t-\mathrm{BuOH})$ were used as the solvents $\left(10 \mathrm{~cm}^{3}\right)$ and the experiments were carried out at two temperatures: room temperature $\left(25^{\circ} \mathrm{C}\right)$ and $50{ }^{\circ} \mathrm{C}$. The reactions were quenched by the addition of an aqueous $0.4 \mathrm{~mol} \mathrm{dm}^{-3}$ solution of $\mathrm{Na}_{2} \mathrm{SO}_{4}$, followed by extraction with $10 \mathrm{~cm}^{3}$ of diethyl ether. The ether layer was dried with anhydrous $\mathrm{Na}_{2} \mathrm{SO}_{4}$ and analyzed by GC. Retention times and mass spectra compared with standards were used to characterize most of the reaction products. Yields were calculated taking into account the different response factors to FID of the substrate (cyclohexane) and products (cyclohexanol and cyclohexanone) through external standardization. For cyclohexyl hydroperoxide, the response factor to FID was considered to be the same as that of cyclohexanol. The aqueous phase was titrated with $\mathrm{NaOH}$ to quantify the total acid compounds obtained in the reaction, expressed as adipic acid.

\section{Supplementary Information}

The crystallographic data (atomic coordinates and equivalent isotropic displacement parameters, calculated hydrogen atom parameters, anisotropic thermal parameters and bond lengths and angles) have been deposited at the Cambridge Crystallographic Data Center (deposition numbers CCDC 672086 and CCDC 672087). Copies of this information may be obtained free of charge from: CCDC, 12 Union Road, Cambridge, CB2 1EZ, UK (Fax: +44-1223-336-033; e-mail: deposit@ccdc.cam.ac.uk or http://www.ccdc.cam.ac.uk).

\section{Acknowledgments}

The authors are grateful for the financial support received from CNPq (Jovens Pesquisadores and INCT-Catálise), CAPES, FAPERJ (Jovem Cientista do Nosso Estado, Pronex) and FUJB. The authors also thank Dr. Manfredo Hörner and Dr. Robert A. Burrow (Departamento de Química, Universidade Federal de Santa Maria) for the crystallographic facilities use.

\section{References}

1. Crabtree, R. H.; Chem. Rev. 1995, 95, 987.

2. Denisov, I. G.; Makris, T. M.; Sligar, S. G.; Schlichting, I.; Chem. Rev. 2005, 105, 2253.

3. Costas, M.; Chen, K.; Que, L. Jr.; Coord. Chem. Rev. 2000, 200, 517; Tshuva, E. Y.; Lippard, S. J.; Chem. Rev. 2004, 104, 987; Bois, J. D.; Mizoguchi, T. J.; Lippard, S. J.; Coord. Chem. Rev. 2005, $200,443$.

4. Que Jr., L.; Tolman, W. B.; Nature 2008, 455, 333.

5. Tang, J.; Gamez, P.; Reedijk, J.; Dalton Trans. 2007, 4644; Pan, Z.; Newcomb, M.; Inorg. Chem. 2007, 46, 6767; Nam, W.; Jin, S. W.; Lim, M. H.; Ryu, J. Y.; Kim, C.; Inorg. Chem. 2002, 41, 3647; Halma, M.; Bail, A.; Wypych, F.; Nakagaki, S.; J. Mol. Catal. A: Chem. 2006, 243, 44; Nakagaki, S.; Castro, K. A. D. F.; Machado, G. S.; Halma, M.; Drechsel, S. M.; Wypych, F.; J. Braz. Chem. Soc. 2006, 17, 1672; Wada, A.; Ogo, S.; Nagatomo, S.; Kitagawa, T.; Watanabe, Y.; Jitsukawa, K.; Masuda, H.; Inorg. Chem. 2002, 
41, 616; England, J.; Britovsek, G. J. P.; Rabadia, N.; White, A. J. P.; Inorg. Chem. 2007, 46, 3752.

6. Olsen, M. H. N.; Salomão, G. C.; Drago, V.; Fernandes, C.; Horn, A. Jr.; Cardozo-Filho, L.; Antunes, O. A. C.; J. Supercrit. Fluids 2005, 34, 119; Salomão, G. C.; Olsen, M. H. N.; Drago, V.; Fernandes, C.; Cardozo-Filho, L.; Antunes, O. A. C.; Catal. Commun. 2007, 8, 69; Esmelindro, M. C.; Oestreicher, E. G.; Márquez-Alvarez, H.; Dariva, C.; Egues, S. M. S.; Fernandes, C.; Bortoluzzi, A. J.; Drago, V.; Antunes, O. A. C.; J. Inorg. Biochem. 2005, 99, 2054.

7. Carvalho, N. M. F.; Horn, A. Jr.; Antunes, O. A. C.; Appl. Catal., A 2006, 305, 140.

8. Silva, G. C.; Parrilha, G. L.; Carvalho, N. M. F.; Drago, V.; Fernandes, C.; Horn, A. Jr.; Antunes, O. A. C.; Catal. Today 2008, 133, 684 .

9. Rosenzweig, A. C.; Frederick, C. A.; Lippard, S. J.; Nordlund, P.; Nature 1993, 366, 537; Whittington, D. A.; Lippard, S. J.; J. Am. Chem. Soc. 2001, 123, 827.

10. Basch, H.; Mogi, K.; Musaev, D. G.; Morokuma, K.; J. Am. Chem. Soc. 1999, 121, 7249.

11. Zang, Y.; Dong, Y.; Que, L. Jr.; Kauffmann, K.; Muenck, E.; J. Am. Chem. Soc. 1995, 117, 1169.

12. Dong, Y.; Fujii, H.; Hendrich, M. P.; Leising, R. A.; Pan, G.; Randall, C. R.; Wilkinson, E. C.; Zang, Y.; Que, L. Jr.; Fox, B. G.; Kauffmann, K.; Münck, E.; J. Am. Chem. Soc. 1995, 117, 2778; Hsu, H. F.; Dong, Y.; Shu, L.; Young, V. G. Jr.; Que, L. Jr.; J. Am. Chem. Soc. 1999, 121, 5230.

13. Kryatov, S. V.; Taktak, S.; Korendovych, I. V.; Rybak-Akimova, E. V.; Kaizer, J.; Torelli, S.; Shan, X.; Mandal, S.; MacMurdo, V. L.; Payeras, A. M.; Que, L. Jr.; Inorg. Chem. 2005, 44, 85; Kim, S. O.; Sastri, C. V.; Seo, M. S.; Kim, J.; Nam, W.; J. Am. Chem. Soc. 2005, 127, 4178; Li, F.; Wang, M.; Ma, C.; Gao, A.; Chen, H.; Sun, L.; Dalton Trans. 2006, 2427; Zhang, X.; Furutachi, H.; Fujinami, S.; Nagatomo, S.; Maeda, Y.; Watanabe, Y.; Kitagawa, T.; Suzuki, M.; J. Am. Chem. Soc. 2005, 127, 826.

14. Pardo, E.; Lloret, F.; Carrasco, R.; Muñoz, M. C.; TemporalSánchez, T.; Ruiz-García, R.; Inorg. Chim. Acta 2004, 357, 2713.

15. Britovsek, G. J. P.; England, J.; White, A. J. P.; Inorg. Chem. 2005, 44,8125 .

16. Carson, E. C.; Lippard, S. J.; Inorg. Chem. 2006, 45, 837; Britovsek, G. J. P.; England, J.; Spitzmesser, S. K.; White, A. J. P.; Williams, D. J.; Dalton Trans. 2005, 945; Nan, W.; Acc. Chem. Res. 2007, 40, 522.

17. Schuchardt, U.; Cardoso, D.; Sercheli, R.; Pereira, R.; Cruz, R. S.; Guerreiro, M. C.; Mandelli, D.; Spinacé, E.V.; Pires, E. L.; Appl. Catal., A 2001, 211, 1 .

18. Carvalho, N. M. F.; Horn, A. Jr.; Bortoluzzi, A. J.; Drago, V.; Antunes, O. A. C.; Inorg. Chim. Acta 2006, 359, 90.

19. Carvalho, N. M. F.; Horn, A. Jr.; Faria, R. B.; Bortoluzzi, A. J.; Drago, V.; Antunes, O. A. C.; Inorg. Chim. Acta 2006, 359, 4250.

20. Carvalho, N. M. F.; Antunes, O. A. C.; Horn, A. Jr.; Dalton Trans. 2007, 1023.

21. Parrilha, G. L.; Fernandes, C.; Bortoluzzi, A. J.; Szpoganicz, B.;
Silva, M. S.; Pich, C. T.; Terenzi, H.; Horn, A. Jr.; Inorg. Chem. Commun. 2008, 11, 643.

22. Horn, A. Jr.; Fernandes, C.; Bortoluzzi, A. J.; Vugman, N. V.; Herbst, M. H.; J. Mol. Struct. 2005, 749, 96; Fernandes, C.; Parrilha, G. L.; Lessa, J. A.; Santiago, L. J. M.; Kanashiro, M. M.; Boniolo, F. S.; Bortoluzzi, A. J.; Vugman, N. V.; Herbst, M. H.; Horn, A. Jr.; Inorg. Chim. Acta 2006, 359, 3167.

23. Lessa, J. A.; Horn, A. Jr.; Pinheiro, C. B.; Farah, L. L.; Eberlin, M. N.; Benassi, M.; Catharino, R. R.; Fernandes, C.; Inorg. Chem. Commun. 2007, 10, 863.

24. Hazell, A.; Jensen, K. B.; Mckenzie, C. J.; Toftlund, H.; Inorg. Chem. 1994, 33, 3127.

25. Nivorozhkin, A. L.; Anxolabéhère-Mallart, E.; Mialane, P.; Davydov, R.; Guilhem, J.; Cesario, M.; Audière, J.-P.; Girerd, J.-J.; Styring, S.; Schussler, L.; Seris, J.-L.; Inorg. Chem. 1997, 36, 846.

26. Horn, A. Jr.; Neves, A.; Vencato, I.; Drago, V.; Zucco, C.; Werner, R.; Haase, W.; J. Braz. Chem. Soc. 2000, 11, 7; Horn, A. Jr.; Vencato, I.; Bortoluzzi, A. J.; Horner, R.; Silva, R. A. N.; Szpoganicz, B.; Drago, V.; Terenzi, H.; de Oliveira, M. C. B.; Werner, R.; Haase, W.; Neves, A.; Inorg. Chim. Acta 2005, 358, 339; Horn, A. Jr.; Vencato, I.; Bortoluzzi, A. J.; Drago, V.; Novak, M. A.; Neves, A.; J. Braz. Chem. Soc. 2006, 17, 1584.

27. Greenwood, N. N.; Gibb, T.C.; Mössbauer Spectroscopy, Chapman and Hall: London, 1971.

28. Marchi-Delapierre, C.; Jorge-Robin, A.; Thibon, A.; Ménage, S.; Chem. Commun. 2007, 1166; Nagataki, T.; Tachi, Y.; Itoh, S.; J. Mol. Catal. A: Chem. 2005, 225, 103; Taktak, S.; Kryatov, S. V.; Rybak-Akimova, E. V.; Inorg. Chem. 2004, 43, 7196.

29. Wilkinson, E. C.; Dong, Y.; Que, L. Jr.; J. Am. Chem. Soc. 1994, 116, 8394; Ito, S.; Okuno, T.; Matsushima, H.; Tokii, T.; Nishida, Y.; J. Chem. Soc., Dalton Trans. 1996, 4037; Norman, R. E.; Holz, R. C.; Ménage, S.; O'Connor, C. J.; Zhang, J. H.; Que, L. Jr.; Inorg. Chem. 1990, 29, 4629.

30. Costes, J.-P.; Tommasino, J.-B.; Carré, B.; Soulet, F.; Fabre, P.-L.; Polyhedron 1995, 14, 771.

31. Li, F.; Wang, M.; Ma, C.; Gao, A.; Chen, H.; Sun, L.; Dalton Trans. 2006, 2427.

32. Wang, X.; Wang, S.; Li, L.; Sundberg, E. B.; Gacho; G. P.; Inorg. Chem. 2003, 42, 7799.

33. Leising, R. A.; Kim, J.; Pérez, M. A.; Que, L. Jr.; J. Am. Chem. Soc. 1993, 115, 9524.

34. Ito, S.; Okuno, T.; Matsushima, H.; Tokii, T.; Nishida, Y.; J. Chem. Soc., Dalton Trans. 1996, 4479.

35. Gagne, R. R.; Koval, C. A.; Lisensky, G. C.; Inorg. Chem. 1980, 19, 2854.

36. Geary, W.; Coord. Chem. Rev. 1971, 7, 81.

37. Spek, A. L.; Acta Crystallogr., Sect. A: Found. Crystallogr. 1990, 46, C34.

Received: March 31, 2009

Web Release Date: December 11, 2009 